\title{
QUANTIFICATION OF PERMANENT AND VARIABLE CHARGES IN REFERENCE SOILS OF THE STATE OF PERNAMBUCO, BRAZIL ${ }^{(1)}$
}

\author{
Jailson Cavalcante Cunha ${ }^{(2)}$, Hugo Alberto Ruiz ${ }^{(3)}$, Maria Betânia Galvão dos Santos \\ Freire $^{(4)}$, Víctor Hugo Alvarez V. ${ }^{(5)}$ \& Raphael Bragança Alves Fernandes ${ }^{(6)}$
}

\begin{abstract}
SUMMARY
The electrical charges in soil particles are divided into structural or permanent charges and variable charges. Permanent charges develop on the soil particle surface by isomorphic substitution. Variable charges arise from dissociation and association of protons $\left(\mathrm{H}^{+}\right)$, protonation or deprotonation, and specific adsorption of cations and anions. The aim of this study was to quantify the permanent charges and variable charges of Reference Soils of the State of Pernambuco, Brazil. To do so, 24 subsurface profiles from different regions (nine in the Zona da Mata, eight in the Agreste, and seven in the Sertão) were sampled, representing approximately $80 \%$ of the total area of the state. Measurements were performed using cesium chloride solution. Determination was made of the permanent charges and the charges in regard to the hydroxyl functional groups through selective ion exchange of $\mathrm{Cs}^{+}$by $\mathrm{Li}^{+}$and $\mathrm{Cs}^{+}$by $\mathrm{NH}_{4}^{+}$, respectively. All the soils analyzed exhibited variable cation exchange capacity, with proportions from 0.16 to 0.60 and an average of 0.40 when related to total cation exchange capacity.
\end{abstract}

Index terms: clays, cation exchange capacity, structural charges, pH dependent charges.

(1) Part of the Master Dissertation in Soil Science and Plant Nutrition of the first author, University of Viçosa - UFV. Received for publication on September 13, 2013 and approved on May 16, 2014.

(2) Postdoctoral Fellow, Rural Federal University of Pernambuco, Agronomy Department - UFRPE/DEPA. Rua Dom Manoel de Medeiros, s/n, Dois Irmãos. CEP 52171-900 Recife (PE), Brazil. E-mail: jailson.c.c.@gmail.com

(3) Visiting Professor, University of Espírito Santo. Alto Universitário, s/n. CEP 29500-000 Alegre (ES), Brazil. E-mail: hruiz@ufv.br

(4) Associate Professor, UFRPE/DEPA. E-mail: betania@depa.ufrpe.br

(5) Full Professor, Department of Soil Science, Federal University of Viçosa - DPS/UFV. Av. P. H. Rolfs, s/n. CEP 36570-900 Viçosa (MG), Brazil. E-mail: vhav@ufv.br

(6) Associate Professor, DPS/UFV. CNPq fellowship. E-mail: raphael@ufv.br 


\title{
RESUMO: QUANTIFICAÇÃO DE CARGAS PERMANENTES E VARIÁVEIS EM SOLOS DE REFERENNCIA DO ESTADO DE PERNAMBUCO, BRASIL
}

\begin{abstract}
As cargas elétricas nas partículas dos solos são divididas em estruturais ou permanentes e variáveis. As primeiras desenvolvem-se na superfície da partícula do solo por substituição isomórfica; as segundas, no entanto, evidenciam-se por meio de dissociação e associação de prótons $\left(\mathrm{H}^{+}\right)$, protonação ou desprotonação e adsorção específica de cátions e ânions. Oobjetivo deste trabalho foi quantificar as cargas permanentes e as variáveis, em solos de referência do Estado de Pernambuco. Para atingir os objetivos, foram retiradas amostras subsuperficiais de 24 perfis em diferentes regiões (nove da Zona da Mata, oito do Agreste e sete do Sertão), que representam aproximadamente $80 \%$ da área total desse Estado. As determinações realizadas, utilizando solução de cloreto de césio, permitiram quantificar as cargas permanentes e as referentes aos grupos funcionais hidroxila, por meio da troca iônica seletiva de $\mathrm{Cs}^{+}$por $\mathrm{Li}^{+}$e de $\mathrm{Cs}^{+}$por $\mathrm{NH}_{4}^{+}$, respectivamente. Todos os solos analisados apresentaram capacidade de troca catiônica variável, com proporções no intervalo de 0,16 a 0,60 e média de 0.40, quando relacionada com a capacidade de troca catiônica total.
\end{abstract}

Termos de indexação: argilas, capacidade de troca catiônica, cargas estruturais, cargas dependentes do $\mathrm{pH}$.

\section{INTRODUCTION}

The study of electric charges in clays is important for an understanding of various physicochemical phenomena in the soil because most electrochemical reactions take place at the surface of these clay particles. This analysis is also important for interpreting the results of soil dispersion in response to the use of different sodic solutions in soil particlesize analysis.

Electric charges of soil mineral particles are divided into structural or permanent charges and variable charges. Permanent charges develop on the soil particle surface through isomorphic substitution. Variable charges, in contrast, result from proton $\left(\mathrm{H}^{+}\right)$ dissociation and association, protonation or deprotonation, and specific adsorption of cations and anions.

Permanent charges originate from isomorphic ionic substitution in the mineral structure and are manifested at any soil pH (Sposito, 2008). This charge is inherent to the mineral and can also be called a structural charge. Isomorphic ionic substitutions, also referred to as isomorphic substitutions, occur in primary minerals, in their magmatic differentiation, and in secondary minerals in their formation in the soil or through inheritance from primary minerals.

Permanent charges can be either negative or positive. Nevertheless, due to the ionic dimensions, a lower valence cation usually substitutes a higher valence one $\left(\mathrm{Al}^{3+}\right.$ replacing $\mathrm{Si}^{4+}, \mathrm{Mg}^{2+}$ replacing $\mathrm{Al}^{3+}$, etc.), which causes a positive charge deficit in the crystalline structure and leads to the emergence of negative charges at the surface of soil mineral particles.

Data on permanent electric charges, which constitute the surface charge of soil particles, are extremely important for an understanding and prediction of the fate of chemical elements in the soil. The 2:1-type clay minerals have predominantly permanent charges. The presence of structural electric charges in minerals is essential for maintaining nutrients in the soil since they appear at any $\mathrm{pH}$ value, unlike variable-charge minerals, which mostly have a high zero point charge (ZPC), thus originating a net positive charge at a $\mathrm{pH}$ considered optimal for most crops.

Variable charges are those originating from the adsorption of ions onto the surface of organic and mineral soil particles, with the net charge being determined by the ion adsorbed in excess. Ions capable of interfering with the charge when adsorbed are called potential-determining ions, $\mathrm{H}^{+}$and $\mathrm{OH}^{-}$being the main ones in the soil solution. Kaolinite, goethite, hematite, and gibbsite are the main soil minerals with this characteristic (Fontes et al., 2001).

The possibility of hydroxylation at the surface is essential to the formation and development of charges in the inorganic constituents with predominance of variable charges. In the presence of water, elements such as $\mathrm{Si}, \mathrm{Al}$, or $\mathrm{Fe}$, for instance, located at the surface of minerals like kaolinite, goethite, hematite, and gibbsite, fill their coordination layer with hydroxyl ions, such that the surface becomes hydroxylated.

Some methods have been proposed to quantify the surface charges of soil particles, among which are ion retention, potentiometric titration, electrokinetic techniques, salt titration, and the mineral addition technique.

A method proposed in the 1990s allows measurement of the structural permanent charge $\left(\sigma_{0}\right)$ and, at the same time, measurement of the proton charge density $\left(\sigma_{\mathrm{H}}\right)$, together with cation and ion adsorption (Anderson \& Sposito, 1991). This method is based on the use of a cesium chloride solution and it allows quantification of the structural permanent 
charge and the charges related to the hydroxyl functional groups through ionic exchange of $\mathrm{Cs}^{+}$by $\mathrm{Li}^{+}$and $\mathrm{Cs}^{+}$by $\mathrm{NH}_{4}{ }^{+}$, respectively. The success of the method has been shown by Chorover \& Sposito (1995), Fontes \& Sposito (1995), Peixoto et al. (1995), and Weber et al. (2005).

The State of Pernambuco, Brazil, has a soil heterogeneity represented by a network of 35 profiles with distinct classifications, allowing thorough examination regarding the origin of the electric charges in the soil. Identification of the contribution of each component to the generation of electric charges in soil particles (permanent or variable electric charges) allows us to obtain important information to understand soil behavior in regard to genesis, chemistry, physics, and fertility, among other areas of soil science.

The aim of this study was to quantify the permanent and variable charges in Reference Soils of the state of Pernambuco, Brazil, according to the classification of a team of soil scientists from the Universidade Federal Rural de Pernambuco (Federal Rural University of Pernambuco) (Ribeiro et al., 1999; Biondi et al., 2011).

\section{MATERIALS AND METHODS}

To achieve these objectives, subsurface samples were taken from 24 profiles (nine from the Zona da Mata, eight from the Agreste, and seven from the Sertão), which represent approximately $80 \%$ of the total area of the state (Table 1). The Zona da Mata, Agreste, and Sertão are meso-regions of the state of Pernambuco arising from division of Brazil into geographic meso- and micro-regions (IBGE, 1990).

After collection, samples were air dried, soil clods were broken up, and the material was passed through a No. 10 sieve (2-mm grid). The $\mathrm{pH}$ in water and in $1 \mathrm{~mol} \mathrm{~L}^{-1} \mathrm{KCl}$ (1:2.5 ratio) (Embrapa, 1997) were determined to characterize the samples and to allow calculation of the $\mathrm{pH}$. Organic carbon was measured through the wet oxidation method (Yeomans \& Bremner, 1988) (Table 2). Clay proportion was also determined (Ruiz, 2005) (Table 3). In addition, mineralogical analysis was performed through X-ray diffraction of the clay fraction, which was separated from the samples after particle-size analyses and mounted on an oriented glass slide through the smear technique. A diffractometer X'Pert Pro (PANalytical) was used, with CoK $\alpha$ radiation and irradiation from 4 to $45^{\circ} 2 \theta$, with a $2 \theta$ step size of 0.01 and a step time of $1 \mathrm{~s}^{-1}$, tension of $40 \mathrm{kV}$, and current of $30 \mathrm{~mA}$.

In order to quantify the permanent and variable electric charges, the method proposed by Anderson \& Sposito (1991) and modified by Weber et al. (2005) was adapted. The different steps are presented below:
- $24 \mathrm{~g}$ of a $0.5 \mathrm{~mol} \mathrm{~kg}^{-1}$ solution of $\mathrm{CsCl}$ was added to $3.5 \mathrm{~g}$ samples of air-dried soil in $50 \mathrm{~mL}$ polycarbonate centrifuge tubes. The suspension was shaken for 25 min using a reciprocal shaker, removing the light organic fraction from the supernatant. It was then centrifuged for $35 \mathrm{~min}$ with a relative centrifugal force (RCF) of $1,710 \mathrm{~g}$, discarding the supernatant solution. The ion $\mathrm{Cs}^{+}$present in the reagent is non-radioactive (Cs-133), of low risk, and when combined with $\mathrm{Cl}^{-}$it forms a compound similar to K compounds; therefore, no special caution is required regarding its disposal, but the basic recommendations of reagent use and disposal must be strictly followed;

- RCF was calculated as follows: $\mathrm{RCF}=0.00001118 \times$ $R \times N^{2}$, where $R$ is the centrifugation radius, in cm, and $\mathrm{N}$ is the centrifugation speed, in rotations per minute;

-The previous procedure of shaking and centrifugation was repeated with the remainder of the soil sample, adding $20 \mathrm{~g}$ of $\mathrm{CsCl}$ solution, but with the concentration reduced to $0.1 \mathrm{~mol} \mathrm{~kg}^{-1}$. The supernatant solution was then discarded and the procedure was performed two more times, one with a $0.1 \mathrm{~mol} \mathrm{~kg}^{-1}$ solution and another with a $0.05 \mathrm{~mol} \mathrm{~kg}{ }^{-1}$ solution. The supernatant solutions were discarded;

- The remaining soil paste was homogenized with the aid of a glass stirring rod, and then put in porcelain evaporating dishes. Then, two $0.5 \mathrm{~g}$ subsamples were taken in order to determine moisture content and assist in calculations involving the mass of the dry soil paste $\left(\mathrm{M}_{\mathrm{DSP}}\right)$;

- After drying $\left(100^{\circ} \mathrm{C}\right)$ for $48 \mathrm{~h}$, quantities of $0.35 \mathrm{~g}$ of $\mathrm{M}_{\mathrm{DSP}}$ from each previous subsample were transferred to $50 \mathrm{~mL}$ centrifuge tubes which received $3.5 \mathrm{~g}$ of a $0.05 \mathrm{~mol} \mathrm{~kg}^{-1}$ solution of $\mathrm{CsCl}$ at $\mathrm{pH} 7.0$. The suspensions were shaken for $60 \mathrm{~min}$ in a horizontal shaker and centrifuged at $1,710 \mathrm{~g}$ for $15 \mathrm{~min}$, discarding the supernatant;

- After that, subsamples were washed in $30 \mathrm{~g}$ of an ethanol:water solution (95:5, volume:volume). In this procedure, the suspensions were shaken for $10 \mathrm{~s}$ in a Vortex mixer, immersed in an ultrasonic bath for 5 $\mathrm{min}$, and once more shaken in a Vortex mixer for $10 \mathrm{~s}$;

- The suspensions were once more centrifuged at $1,710 \mathrm{~g}$ for $30 \mathrm{~min}$, discarding the supernatant solutions. Washing was repeated until no chloride was detected after a test with a $0.01 \mathrm{~mol} \mathrm{~kg}^{-1}$ solution of $\mathrm{AgNO}_{3}$. The centrifuge tubes were placed in a laboratory oven and dried at $65^{\circ} \mathrm{C}$ for $48 \mathrm{~h}$;

- The purpose of washing with ethanol and drying the samples was to reduce the concentration of embedded $\mathrm{Cs}^{+}$and favor the formation of internal sphere complexes between $\mathrm{Cs}^{+}$and siloxane surfaces;

- The soil samples prepared as indicated received $30 \mathrm{~g}$

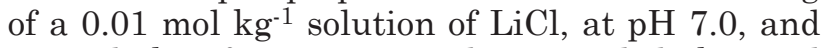
were shaken for $30 \mathrm{~min}$ in a horizontal shaker and centrifuged at 1,710 $\mathrm{g}$ for $40 \mathrm{~min}$, thus extracting $\mathrm{Cs}^{+}$ ions from the ionizable functional groups; 
Table 1. Classification lithology and sampled horizon $(\mathrm{H})$ of the studied reference soils of the State of Pernambuco

\begin{tabular}{|c|c|c|c|c|}
\hline Profile $^{(1)}$ & $\operatorname{SiBCS}^{(2)}$ & Soil Taxonomy ${ }^{(3)}$ & Lithology & $\mathbf{H}$ \\
\hline \multicolumn{5}{|c|}{ Zona da Mata ${ }^{(4)}$} \\
\hline 1 & Argissolo Vermelho-Amarelo & Ultisols. Oxisols (Kandic) & Gneiss & Bt1 \\
\hline 2 & Argissolo Amarelo & Ultisols. Oxisols (Kandic) & Barreiras Group & Bt1 \\
\hline 4 & Argissolo Vermelho-Amarelo & Ultisols. Oxisols (Kandic) & Gneiss e migmatites & Bt1 \\
\hline 5 & Chernossolo Argilúvico & Molisols & Gneiss & $\mathrm{Bt}$ \\
\hline 6 & Latossolo Amarelo & Oxisols & $\begin{array}{l}\text { Similar material to Barreiras Group } \\
\text { covering again crystalline } \\
\text { basement }\end{array}$ & Bw 1 \\
\hline 7 & Nitossolo Vermelho & $\begin{array}{l}\text { Ultisols. Oxisols (Kandic). } \\
\text { Alfisols }\end{array}$ & Basic volcanic rocks & Bt1 \\
\hline 8 & Argissolo Vermelho & Ultisols. Oxisols (Kandic) & Gneiss & Bt1 \\
\hline 9 & Plintossolo Argilúvico & Ultisols (Plintaquults) & Barreiras Group & $2 \mathrm{Bt}$ \\
\hline 10 & Argissolo Amarelo & Ultisols. Oxisols (Kandic) & Barreiras Group & Btx \\
\hline \multicolumn{5}{|c|}{ Agreste } \\
\hline 14 & Planossolo Háplico & $\begin{array}{l}\text { Ultisols (Albaquults and } \\
\text { Plintaquullts). Alfisols } \\
\text { (Albaquults and Plintaquullts) }\end{array}$ & $\begin{array}{l}\text { Medium equigranular leucocratic } \\
\text { biotite-gneiss }\end{array}$ & $2 \mathrm{Bt}$ \\
\hline 15 & Planossolo Háplico & $\begin{array}{l}\text { Ultisols (Albaquults and } \\
\text { Plintaquullts). Alfisols } \\
\text { (Albaquults and Plintaquullts) }\end{array}$ & Coarse equigranular diorite & $2 \mathrm{Bt}$ \\
\hline 16 & Argissolo Vermelho & Ultisols. Oxisols (Kandic) & $\begin{array}{l}\text { Coarse equigranular leucocratic } \\
\text { biotite-gneiss }\end{array}$ & Bt1 \\
\hline 18 & Argissolo Amarelo & Ultisols. Oxisols (Kandic) & $\begin{array}{l}\text { Biotite-muscovite- quartzite of fine to } \\
\text { medium-grained. with quartz veins }\end{array}$ & Bt \\
\hline 19 & Planossolo Nátrico & $\begin{array}{l}\text { Alfisols (Natrusalfs and } \\
\text { Natrudalfs) }\end{array}$ & $\begin{array}{l}\text { Banded biotite-gneiss of medium- } \\
\text { grained with quartz veins }\end{array}$ & $2 \mathrm{Btn}$ \\
\hline 20 & Latossolo Vermelho-Amarelo & Oxisols & $\begin{array}{l}\text { Coarse titanite-amphibole-biotite- } \\
\text { granodiorite with plagioclase porphyry }\end{array}$ & Bw 1 \\
\hline 21 & Argissolo Vermelho-Amarelo & Ultisols. Oxisols (Kandic) & $\begin{array}{l}\text { Leucocratic sillimanite-biotite- } \\
\text { muscovite-gneiss of medium grained }\end{array}$ & $\mathrm{Bt}$ \\
\hline 22 & Argissolo Amarelo & Ultisols. Oxisols (Kandic) & Covering little thick on crystalline rocks & Btx \\
\hline \multicolumn{5}{|c|}{ Sertão } \\
\hline 23 & Argissolo Amarelo & Ultisols. Oxisols (Kandic) & Crystalline rocks (Mica Schist) & Bt1 \\
\hline 24 & Planossolo Nátrico & $\begin{array}{l}\text { Alfisols (Natrusalfs and } \\
\text { Natrudalfs) }\end{array}$ & $\begin{array}{l}\text { Covering little thick of material } \\
\text { reported to Tertiary/Quaternary } \\
\text { about rocks from Precambrian }\end{array}$ & Btn2 \\
\hline 29 & Luvissolo Crômico & Adirisols (Argids) & $\begin{array}{l}\text { Mica Schist and gneiss from } \\
\text { Undivided Precambrian }\end{array}$ & $2 \mathrm{Bt}$ \\
\hline 30 & Latossolo Amarelo & Oxisols & $\begin{array}{l}\text { Material from Undivided } \\
\text { Precambrian with covering again } \\
\text { de material reported to } \\
\text { Tertiary/Quaternary }\end{array}$ & Bw 1 \\
\hline 31 & Cambissolo Háplico & Inceptisols & Granites and syenites & Bi1 \\
\hline 32 & \multicolumn{3}{|c|}{ limestones. marls. siltstone and gibbsite } & Biv \\
\hline 33 & Argissolo Amarelo & Ultisols. Oxisols (Kandic) & $\begin{array}{l}\text { Material from Precambrian with } \\
\text { covering again of material reported } \\
\text { to Tertiary/Quaternary }\end{array}$ & $\mathrm{Bt}$ \\
\hline
\end{tabular}

${ }^{(1)}$ Numbering attributed by the Federal Rural University of Pernambuco to the reference soils of the state. ${ }^{(2)}$ Brazilian Soil Classification System. ${ }^{(3)}$ Correspondence based on Embrapa (2013). ${ }^{(4)}$ Location region of the profile in the State of Pernambuco. 
Table 2. $\mathrm{pH}\left(\mathrm{H}_{2} \mathrm{O}\right.$ and $\left.\mathrm{KCl}\right), \Delta \mathrm{pH}$, organic carbon $(\mathrm{OC})$ and principal clay minerals of the sampled horizons (H) of reference soils of the State of Pernambuco

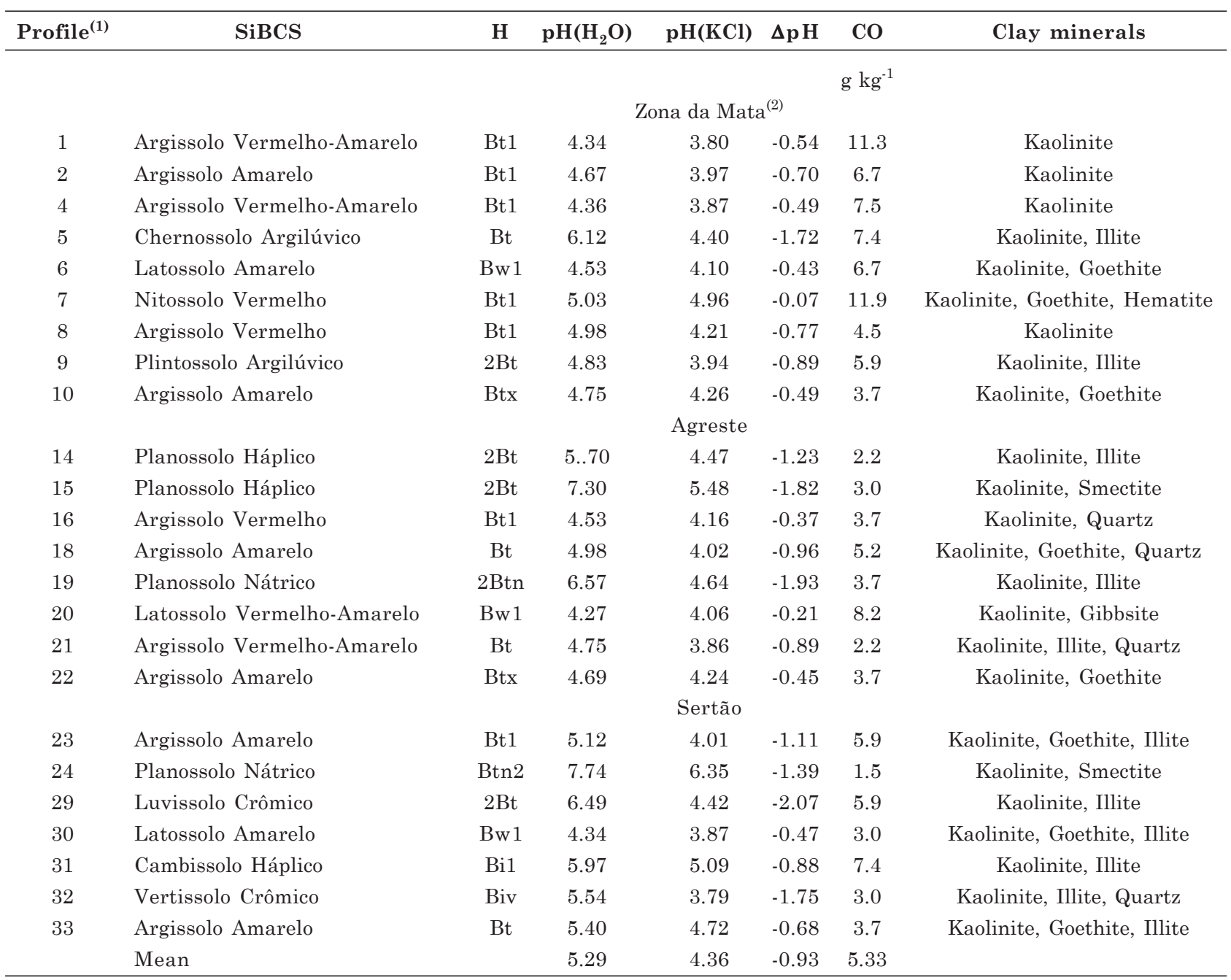

(1) Numbering attributed by the Federal Rural University of Pernambuco to the reference soils of the state. ${ }^{(2)}$ Location region of the profile in the State of Pernambuco.

-The supernatant solutions were transferred to plastic containers and weighed. The centrifuge tubes, with the remaining soil and the embedded solution, were also weighed [ $\left.\mathrm{M}_{(\mathrm{CTS}+\mathrm{ES})}\right]$, obtaining the mass of the embedded solution through this difference $\left[\mathrm{M}_{\mathrm{ES}}=\right.$ $\left.\mathrm{M}_{\text {(CTS + ES) }}-\mathrm{M}_{\mathrm{CTS}}\right]$;

- The $\mathrm{Cs}^{+}$was then extracted from the sites with structural charge by adding $30 \mathrm{~g}$ of $1.0 \mathrm{~mol} \mathrm{~kg}-1$ solution of ammonium acetate $\left(\mathrm{NH}_{4} \mathrm{OAc}\right)$. The suspension was shaken for $30 \mathrm{~min}$ in a horizontal shaker and centrifuged at $1,710 \mathrm{~g}$ for $10 \mathrm{~min}$. This extraction was performed three times, gathering the supernatant in a plastic container;

- $\mathrm{Cs}^{+}$determinations in the extracts of $\mathrm{LiCl}$ and $\mathrm{NH}_{4} \mathrm{OAc}$ were performed through ICP-OES (Inductively Coupled Plasma - Optical Emission Spectrophotometry), belonging to the Federal University of Viçosa, at the wavelength of $455.5 \mathrm{~nm}$;
- The variable charge, $\mathrm{CECV}\left(\mathrm{mol}_{\mathrm{c}} \mathrm{kg}^{-1}\right.$ of soil), was determined by quantifying the exchangeable $\mathrm{Cs}^{+}$ released from the surface after equilibrium of the sample with $\mathrm{LiCl}$ :

$$
C E C V=k_{C s(\text { LiCl })}\left(\frac{M_{L i C l(\text { added })}}{M_{C T S}}\right)
$$

where $\mathrm{k}_{\mathrm{Cs}(\mathrm{LiCl})}$ is the $\mathrm{Cs}^{+}$concentration in the $\mathrm{LiCl}$

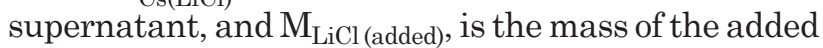
$\mathrm{LiCl}$ solution (supernatant solution + embedded solution);

The permanent charge, CECP $\left(\mathrm{mol}_{\mathrm{c}} \mathrm{kg}^{-1}\right.$ of soil), was calculated as the excess of retained $\mathrm{Cs}^{+}$after saturation of the exchange complex with $\mathrm{NH}_{4}{ }^{+}$to substitute the $\mathrm{Cs}^{+}$present in the structure of the minerals (Anderson \& Sposito, 1991):

$C E C P=k_{C s\left(\mathrm{NH}_{4} \mathrm{OAc}\right)}\left(\frac{M_{\mathrm{NH}_{4} \mathrm{OAc}(\text { added })}}{M_{\mathrm{CTS}}}\right)-\left(k_{C s(\mathrm{LiCl})} M_{\mathrm{LiCl}(\text { embedded })}\right)$ 
Table 3. Clay content, permanent cation exchange capacity (CECP), variable cation exchange capacity $(\mathrm{CECV})$, total cation exchange capacity $($ CECT $=$ CECP + CECV) and relation CECV/CECT $(V / T)$ in the sampled horizons $(\mathrm{H})$ of reference soils of the State of Pernambuco

\begin{tabular}{|c|c|c|c|c|c|c|c|}
\hline Profile $^{(1)}$ & SiBCS & $\mathbf{H}$ & Clay & CECP & CECV & CECT & $\mathrm{V} / \mathrm{T}$ \\
\hline & & & $\mathrm{kg} \mathrm{kg}^{-1}$ & 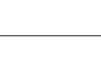 & $\mathrm{cmol}_{\mathrm{c}} \mathrm{kg}$ & & \\
\hline & & & \multicolumn{5}{|c|}{ Zona da Mata ${ }^{(2)}$} \\
\hline 1 & Argissolo Vermelho-Amarelo & Bt1 & 0.590 & 6.56 & 2.89 & 9.45 & 0.31 \\
\hline 2 & Argissolo Amarelo & Bt1 & 0.297 & 5.44 & 1.61 & 7.05 & 0.23 \\
\hline 4 & Argissolo Vermelho-Amarelo & Bt1 & 0.376 & 3.57 & 2.32 & 5.89 & 0.39 \\
\hline 5 & Chernossolo Argilúvico & $\mathrm{Bt}$ & 0.377 & 9.76 & 5.62 & 15.38 & 0.37 \\
\hline 6 & Latossolo Amarelo & $\mathrm{Bw} 1$ & 0.570 & 2.48 & 2.52 & 5.00 & 0.50 \\
\hline 7 & Nitossolo Vermelho & Bt1 & 0.693 & 5.07 & 4.56 & 9.63 & 0.47 \\
\hline 8 & Argissolo Vermelho & Bt1 & 0.419 & 3.17 & 2.99 & 6.16 & 0.49 \\
\hline 9 & Plintossolo Argilúvico & $2 \mathrm{Bt}$ & 0.195 & 3.23 & 1.73 & 4.96 & 0.35 \\
\hline \multirow[t]{2}{*}{10} & Argissolo Amarelo & Btx & 0.589 & 2.98 & 2.00 & 4.98 & 0.40 \\
\hline & & & \multicolumn{5}{|c|}{ Agreste } \\
\hline 14 & Planossolo Háplico & $2 \mathrm{Bt}$ & 0.146 & 2.89 & 1.01 & 3.90 & 0.26 \\
\hline 15 & Planossolo Háplico & $2 \mathrm{Bt}$ & 0.268 & 15.84 & 3.42 & 19.26 & 0.18 \\
\hline 16 & Argissolo Vermelho & Bt1 & 0.417 & 2.50 & 1.79 & 4.29 & 0.42 \\
\hline 18 & Argissolo Amarelo & $\mathrm{Bt}$ & 0.419 & 2.79 & 2.11 & 4.90 & 0.43 \\
\hline 19 & Planossolo Nátrico & $2 \mathrm{Btn}$ & 0.221 & 5.46 & 3.80 & 9.26 & 0.41 \\
\hline 20 & Latossolo Vermelho-Amarelo & Bw 1 & 0.516 & 2.75 & 2.34 & 5.09 & 0.46 \\
\hline 21 & Argissolo Vermelho-Amarelo & $\mathrm{Bt}$ & 0.308 & 2.70 & 1.59 & 4.29 & 0.37 \\
\hline \multirow[t]{2}{*}{22} & Argissolo Amarelo & Btx & 0.627 & 2.54 & 1.85 & 4.39 & 0.42 \\
\hline & & & \multicolumn{5}{|c|}{ Sertão } \\
\hline 23 & Argissolo Amarelo & Bt1 & 0.232 & 2.67 & 1.61 & 4.28 & 0.38 \\
\hline 24 & Planossolo Nátrico & Btn2 & 0.240 & 3.76 & 2.57 & 6.33 & 0.41 \\
\hline 29 & Luvissolo Crômico & $2 \mathrm{Bt}$ & 0.130 & 2.44 & 2.57 & 5.01 & 0.51 \\
\hline 30 & Latossolo Amarelo & Bw 1 & 0.234 & 1.93 & 1.17 & 3.10 & 0.38 \\
\hline 31 & Cambissolo Háplico & Bi1 & 0.307 & 2.03 & 3.03 & 5.06 & 0.60 \\
\hline 32 & Vertissolo Crômico & Biv & 0.311 & 3.88 & 5.36 & 9.24 & 0.58 \\
\hline \multirow[t]{2}{*}{33} & Argissolo Amarelo & $\mathrm{Bt}$ & 0.065 & 2.66 & 1.08 & 3.74 & 0.29 \\
\hline & Mean & & 0.356 & 4.13 & 2.56 & 6.69 & 0.40 \\
\hline
\end{tabular}

(1) Numbering attributed by the Federal Rural University of Pernambuco to the reference soils of the state. ${ }^{(2)}$ Location region of the profile in the State of Pernambuco.

where $\mathrm{k}_{\mathrm{Cs}(\mathrm{NH} 4 \mathrm{OAc})}$ is the concentration of $\mathrm{Cs}^{+}$in the supernatant solution of $\mathrm{NH}_{4} \mathrm{OAc} ; \mathrm{M}_{\mathrm{NH} 4 \mathrm{OAc} \text { (added) }}$ is the mass of the $\mathrm{NH}_{4} \mathrm{OAc}$ solution added, and $\mathrm{M}_{\mathrm{LiCl}(\text { embedded) }}$ is the mass of $\mathrm{LiCl}$ embedded per mass unit of the dry adsorbent.

- The total surface charge, CECT $\left(\mathrm{mol}_{\mathrm{c}} \mathrm{kg}^{-1}\right.$ of soil) was calculated by the sum of CECP and CECV:

$$
\mathrm{CECT}=\mathrm{CECP}+\mathrm{CECV}
$$

\section{RESULTS AND DISCUSSION}

In general, the sampled soils show low values of organic matter $(\mathrm{OM})$, high amplitude in the clay content, and predominance of negative electric charge, indicated by the negative value of $\Delta \mathrm{pH}$ (Tables 2 and 3). Organic carbon (OC) contents ranged from 1.5 to $11.9 \mathrm{~g} \mathrm{~kg}^{-1}$ (average of $5.33 \mathrm{~g} \mathrm{~kg}^{-1}$ ), clay contents from 0.065 to $0.693 \mathrm{~kg} \mathrm{~kg}^{-1}$ (average of $0.356 \mathrm{~kg} \mathrm{~kg}^{-1}$ ), and $\Delta \mathrm{pH}$ from - 0.07 to -2.07 (average of -0.93).

Values of the permanent cation exchange capacity (CECP), variable cation exchange capacity (CECV), total cation exchange capacity $(\mathrm{CECT})[\mathrm{CECT}=\mathrm{CECP}$ $+\mathrm{CECV}]$, and the ratio CECV/CECT (V/T), an indication of the proportion of $\mathrm{pH}$-dependent charges in the diagnostic horizon of the soils studied, are shown in table 3. In four soils, V/T was equal to or greater than 0.50 , which corresponds to approximately $17 \%$ of the diagnostic horizons studied. The lowest $\mathrm{V} / \mathrm{T}$ value was 0.18 , indicating that all the diagnostic horizons studied showed CEC derived from variablecharge material.

Considering all the profiles analyzed, the average V/T ratio was 0.40 (Table 3 ). It should be noted that 
there was no removal of OM from soils in the CEC determination, thus not allowing differentiation between the amounts of $\mathrm{OM}$ and clay minerals contributing to the variable charges for the CECV. To reduce the possible contribution of the OM, determinations were purposely performed with samples from subsurface horizons. Some soils, such as profiles 26 and 33, have low contents of clay and OC, which makes it difficult to infer the amount of CECV originating predominantly from inorganic material. Thus, further research is needed to identify the separate contribution of each constituent present in the soils.

The predominance of CECP in the subsurface horizons of profiles 1, 2, and 4 (Table 3), despite the prevalence of kaolinite in their clay fractions (Table 2), can be explained by the possibility that the method of CEC determination through $\mathrm{Cs}^{+}$adsorption registers the charges available in the 2:1 clay minerals that may be present but not detected by X-ray diffraction applied to the natural clay fraction (with no treatment application).

The $\mathrm{Cs}^{+}$adsorption method, though little studied in Brazilian soils, proves to be an excellent line of research for soil science because despite detecting electric charges originating from 2:1 minerals not identified with X-ray diffractograms in the absence of treatments, such as clay saturation by cations $\left(\mathrm{Mg}^{2+}\right.$ and $\mathrm{K}^{+}$, for instance) to identify materials with uniform expansion of the expansible phyllosilicate (smectites and chlorites, for instance), it would be important in studies on soils with different mineralogies, as well as allowing the observation of the contribution of organic and inorganic constituents to net soil electric charge.

Specifically regarding the representative soils of the State of Pernambuco, the presence of variable charges in all soils of the region should be pointed out. It is sometimes suggested that these soils, especially those from the Sertão region, could have a high proportion of permanent charges in their exchange complexes due to the climatic conditions of the region. The marked presence of materials with variable charge is an indication of past climate conditions that led to the predominant formation of variable charge clay minerals, as well as the possible contribution of kaolinite, which, despite having a low CEC, in large amounts can provide variable electric charges of considerable proportion. The predominance of a more humid past climate in the Northeast region was indicated by De Oliveira et al. (1999) and Pessenda et al. (2010).

\section{CONCLUSIONS}

1. The cesium adsorption method was efficient in the determination of electrical charges in Reference Soils of the state of Pernambuco, allowing to identify different amounts of variable and permanent cation exchange capacity in all analyzed soils.
2. All the soils analyzed exhibited variable cation exchange capacity, with proportions from 0.16 to 0.60 and an average of 0.40 when related to total cation exchange capacity.

\section{LITERATURE CITED}

ANDERSON, S.J. \& SPOSITO, G. Cesium adsorption method for measuring accessible structural surface charge. Soil Sci. Soc. Am. J., 55:1569-1576, 1991.

BIONDI, C.M.; NASCIMENTO, C.W.A. \& FABRICIO NETA, A.B. Teores naturais de bário em solos de referência do estado de Pernambuco. R. Bras. Ci. Solo, 35:1819-1826, 2011.

CHOROVER, J. \& SPOSITO, G. Surface charge characteristics of kaolinitic tropical soils. Geochim. Cosmochim. Acta, 59:875-884, 1995.

DE OLIVEIRA, P.E.; BARRETO, A.M.F. \& SUGUIO, K. Late Pleistocene/Holocene climatic and vegetational history of the Brazilian caatinga: The fóssil dunes of the middle São Francisco River. Palaeogeogr. Palaeoclimatol. Palaeoecol., 152:319-337, 1999.

EMPRESA BRASILEIRA DE PESQUISA AGROPECUÁRIA EMBRAPA. Centro Nacional de Pesquisa de Solos. Sistema brasileiro de classificação de solos. 3.ed. Brasília, 2013. 353p.

EMPRESA BRASILEIRA DE PESQUISA AGROPECUÁRIA EMBRAPA. Manual de métodos de análise de solo. 2.ed. Rio de Janeiro, Centro Nacional de Pesquisa de Solos, 1997. 212p.

FONTES, M.P.F. \& SPOSITO, G. Medição da densidade de carga estrutural acessível em Latossolos brasileiros com diferentes mineralogias. In: CONGRESSO BRASILEIRO DE CIÊNCIA DO SOLO, 25., Viçosa, MG, 1995. Resumos expandidos... Viçosa, MG, Sociedade Brasileira de Ciência do Solo, 1995. v.1, p.292-294.

FONTES, M.P.F.; CAMARGO, O.A. \& SPOSITO, G. Eletroquímica das partículas coloidais e sua relação com a mineralogia de solos altamente intemperizados. Sci. Agric., 58:627-646, 2001.

INSTITUTO BRASILEIRO DE GEOGRAFIA E ESTATÍSTICA - IBGE. Divisão regional do Brasil em mesorregiões e microrregiões geográficas. 1. ed. Rio de Janeiro, Instituto Brasileiro de Geografia e Estatística, 1990. 135p.

PEIXOTO, R.T.G.; TRAINA, S.J. \& BIGHAM, J.M. Aplicabilidade do método de adsorção de Cs na determinação de carga elétrica permanente em Latossolos derivados de basalto no Paraná. In: CONGRESSO BRASILEIRO DE CIÊNCIA DO SOLO, 25., Viçosa, 1995. Resumos expandidos... Viçosa, MG, Sociedade Brasileira de Ciência do Solo, 1995. v.1, p.295-297.

PESSENDA, L.C.R.; GOUVEIA, S.E.M.; RIBEIRA, A.S.; DE OLIVEIRA, P.E. \& ARAVENA, R. Late Pleistocene and Holocene vegetation changes in northeastern Brazil determined from carbon isotopes and charcoal records in soils. Palaeogeogr. Palaeoclimatol. Palaeoecol. 297:597608, 2010. 
RIBEIRO, M.R.; JACOMINE, P.K.T. \& LIMA, J.F.W.F. Caracterização e classificação de solos de referência do Estado de Pernambuco. Recife, Universidade Federal Rural de Pernambuco, 1999. 140p.

RUIZ, H.A. Incremento da exatidão da análise granulométrica do solo por meio da coleta da suspensão (silte+argila). R. Bras. Ci. Solo, 29:297-300, 2005.

SPOSITO, G. The chemistry of soil. 2.ed. New York, Oxford University Press, 2008. 329p.
WEBER, O.L.S.; CHITOLINA, J.C.; CAMARGO, O.A. \& ALLEONI, L.R.F. Método da adsorção de césio para determinação da carga estrutural em solos altamente intemperizados. Bragantia, 64:109-113, 2005.

YEOMANS, J.C. \& BREMNER, J.M. A rapid and precise method for routine determination of carbon in soil. Commun. Soil Sci. Plant Anal., 19:1467-1476, 1988. 